van de juistheid der rechtspraak niets overblijft; de jarenlange ervaring is daar om het tegendeel te bewijzen. Het wordt alleen den rechter minder gemakkelijk gemaakt tot de waarhoid to komen.

Ln nu de accountant. Is het onbeschroomd kumen raadplegen van den accountant cen algemeen belang? Ik antwoord volmondig: ja. Zooals men zich met bezwaren en vragen op geestelijk, lichamelijk of rechtskundig gebied wendt tot geestelijke, medicus of advocaat, zoo wendt men zich met bezwaren en vragen op bedrijfseconomisch gebied tot den accountant. Natuurlijk behartigt de accountant met zijn adviezen in de eerste plaats het persoonlijk belang van zijn cliënt, maar door dit to doen dient hij toch ook een wijder, algemecner belang: het Zakenleven, de Welvaart; hij schept cen deugdelijken grondslag voor het vertrouwen in het ceonomisch verkecr.

En zooals gecstelijke, medicus of advocaat slechts dán onbeschroomd zullen worden geraadpleegd als de hulpzoekende de overtuiging heeft dat de door hem toevert louwde geheimen zelfs niet aan den rechter zullen worden prijsgegeven, zoo geldt ditzelfde voor den accountant, die gerocpen wordt den bedrijfsleider te adviseeren. Krachtens den aard van de hulp dus, welke hij verleent, dient tot hen, dien het verschooningsrecht tockomt, ook de accountant te worden gerekend; hịj ,moet worden he„schouwd als ,un par profession confident nécessaire”, cen onmisbarvertrouwensman, wiens hulp men slechts met ,vrucht ,kan inroepen, als men overtuigd is, dat men alles zonder eenig "gevaal aan hem kan modedeclen"" ). Hocht in het geval, dat de Hcer Branberyen stelt, een accountant in cen eiviel geding weigeren getuigenis af te leggen omtrent het vermogen van cen man (zijn eliënt). die tot betaling van levensonderhoud aan zijn gescheiden vrouw verplicht is, dan zal dit zwijgen van den accountant inderdaad tot gerolg kumm hebben, dat niet is te bewijzen hoe groot het vermogen van dien man is en dat dus aan de vrouw niet het bedrag voor levensonderhoud wordt toegekend, waarop zij recht heeft, zoodat onrecht geschiedt. Maar hetzelfue kan het geval zijn als een advocal den rechter zou weigeren te informeeren met betrekking tot de mededeelingen, welke dezelfde man hem heeft gedalan toen die hem advies kwam vragen. En toch zal die adrocaat zich waarschijnlijk op zijn verschooningsrecht beroepen, terwijl de rechter, even waarschijnlijk, dit beroep zal accepteeren! Waarom? Omdat het algemeen belang, dat ligt in de onbeschroomde raduleging van den advocant moet praevaleeren boven het algemeen belang, dat hierin hestaat dat het den rechter zoo gemakkelijk mogelijk worde gemakkt tot de warheid door te dringen. Voor den accountant geldt, naar mịn meening, volkomen hetzelfde; hij behoort met den geestelijke, den medicus en den advocaat tot de vertrouwenspersonen, aan wier beroep nu eenmaal het in ontvangst nemen van geheimen inhaerent is.

Il behoef er den II eer Branberyen niet alan te herinmeren, dat er ten amzien van de vraag of den geestelijke, den medicus en den advocalat het verschooningsrecht toekomt niet altijd cen communis opinio heeft bestaan, terwijl men het er thans vrijwel over eens is, dat dit recht dezen vertrouwenslieden wel toekomt. Dat een dergelijk commmis opinio nog niet bestaat ten opzichte van den accountant moct m.i. worden toegeschreven aan de omstandigheid dat het accountantsberocp) in zijn tegenwoordige omvang en beteckenis nog van betrekkelịk jongen datum is en nog niet bestond toen roor de andere vertrouwensberoepen de vragen van zwijgrecht en zwijgrplicht aan de orde waren. Nog niet iedereen geeft zich es voldocnde rekenschap van dat zich

2) Mr. S. I. M. Wijthoff, Rechter-Commissaris te Ansterdam, in zijn beschikking van 9 Januarj 1933. bij de genoemde oude vertrouwensberoepen ook het nieuwe van den accountant heeft gevoegd.

De Heer Branbergen wijst tenslotte op het moeilijke en pijnlijke conflict, dat voor den consciëntieuzen accountant kan ontstaan als hij zich in een concreet geval gesteld ziet voor de vraag of hij, als getuige opgeroepen, al of niet zal antwoorden. Voor dit conflict kan iedere vertrouwensman gesteld worden, niet alloen de accountant. Ik las nog onlangs (Algemeen Handelsblad 24 Februari 1937) van een medicus te Hengelo, die oorspronkelijk voor de Rechtbank te Almelo geen inlichtingen wilde geven omtrent den duur van de ziekte van een zijner patiënten. Tengevolge van deze weigering zou het niet mogelijk zijn geweest de schadevergoeding aan den patiënt (het ging om gevolgen van een aanrijding) vast te stellen. Nadat de P'resident van de Rechtbank den medicus hicrop had gewezen, heeft deze de gevraagde rerklaring afgelegd. Ten slotte was het hier de vertrouwensman zelf, die, na afweging der belangen, zijn besluit nam om te spreken.

Ik ben het met den Heer Branbergen eens, dat de minder consciëntieuze vertrouwensman, dus ook de minder consciënticuze accountant, het hier gemakkelijker heeft dan zijn conscënticuze collega. De consciëntieuze accountant evenwel, die in zijn opleiding vertrouwd gemaakt is met de verantwoordelijkheid, welke hij heeft te dragen, zal zich van die verantwoordelijkheid ook bewust zijn als hij de moeilijke vraag: spreken of zwijgen, te beantwoorden krijgt.

I. VAN FSSEN LZn.

\section{NIEUWE REGELING VAN HET TOEZICHT OP JAARREKENINGEN VAN NAAMLOOZE VENNOOTSCHAPPEN IN FRANKRIJK}

In het Februarinummer komt onder bovenstaanden titel een artikel voor met nasehrift van den Heer F. Haarbosch, waarbij in de vertaling van de ministerieele toelichting van het daarbij bedoelde decreet van 29 .Juni 1936 wordt gesproken van de strafrechterlijke verantwoordelijkheid van behcerders en de keuze on de bevocgdheden van commissarissen.

Met deze vertaling van het woord ,,commissaires" in commissariusen zij men echter voorzichtig. De vertaling moge letterlijk juist zijn, zij dekt echter allerminst het begrip van commissarissen zooals wij dat van deze functionarissen in Nederland hebben. I) ,"commissaires" in Frankrijk hebben een geheel andere opdracht dan de commissarissen hier te lande, sterker nog, de commissarissen zooals wij die kennen, bestaan in Frankrijk niet.

De „commissaires" in de Fransehe wetgeving vermeld, zijn degenen, die uitsluitend belast worden met de controle van de jalrregening, derhalve tevens de controle van de boekhouding omvattend, doch zij hebhen niet de taak van de commissarissen volgens Nederlandsch begrip tot het houden van toczicht op het bestumr. De Fransche functionarissen worden in de spreektaal doorgaans aangeduid als ,commissaires aux comptes', warruit duidelijker het verband met de jaarrekening blijkt.

De conclusie van den Heer Haarboseh, dat door de genoemde twee decreten de in Nederland door hem aangeduide mogelijkheid in Frankrijik is uitgeschakeld en dat men in elk geval één deskundigen commissaris heeft, waarmede dan in dit verband cen commissaris volgens onze begrippen wordt bedoeld, is dan ook niet juist. I'iteraurd berust ook de verder'e conclusie terzake ran de vereenighantheid in Frankrijk van de functies op dezelfie dwaling. 
()verigens kumnen de decreten voor de bescherming der spaarders, wolke hun geld aan vemootschappen op aandeelen toevertrouwen van heilzamen invloed zijn. Immers de voorschriften bedoclen paal en perk te stellen aan het veelvuldig voorkomend gebruik, dat de controle van de jaarrekening wordt opgedragen aan hen voor wie de persoonlijke relatie een grootere rol speelt dan de vakkennis. De remuneratie, welke tegelijk bij de benoeming door de algemeene vergadering wordt vastgesteld, is daurbij gewoonlijk van zoodanig bescheiden aard, dat hicrmede onmogelijk degelijk werk kan worden betaald. Het is $n u$ maar te hopen, dat voldoende materiaal aanwezig is, waardoor de decreten aan hun doel kumnen beantwoorden.

Bovenstaande beschouwing, warin werd geconstateerd, dat commissarissen zooals wij die kennen in Frankrijk nict bestaan, zou uiteraard onvolledig zijn, indien niet zou worden vermeld hoe het dan wel met het besturen van een nammlooze vennootschap is gesteld.

Te dezer zake kan worden opgemerkt, dat de structuur in Frankrijk juridisch overeenkomt met de bij ons, althans bij groote naamlooze vennootschappen, minder gebruikelijken vorm, waarbij de leiding uitsluitend berust bij het bestumr dus zonder commissarissen (art. 47 van de Nederlandsche wet op de Naamlooze Vennootschap). Het zijn in Frankrijk on niet alleen aldaar de in den aunvang vermelde beheerders (administrateurs), tezamen rormend de "Conseil d'Administration", die de vennootschap besturen en haal vermogen beheersen.

Bij een grooten Raad van Beheer zou het zeer moeilijk, zoo niet ondoenlijk zijn, indien allen aan het dagelijksch bestuur deelnamen. De praktijk komt hieraan tegemoct door de dnlegatie, waarbij bepaalde bevoegdheden worden overgedragen aan cnkele leden van den Raad, dic dan als ,administrateurs délégués" worden aangewezen. Bij deze regeling heeft men dan de figuur, welke oogenschịnlijk veel overeenkomst vertoont met het bij ons bekende hestuur, belast met de dagelijksche leiding en de commissarissen belast met het toezicht op het bestuul. Men bedenke echter wel, dat hier slechts schijn bestaat, in feite zịn in Frankrijk de ,administrateur's" allen bestuurders.

Bij groote vennootschappen treft men behalve de ,administrateurs" bovendien nog wel functionarissen aan, die den titel van ,directeur's" dragen. Met de letterlijke vertaling zij men ook hier voorzichtig, aangezicn zij het Nederlandsch begrip niet bepaalt. De ,directeurs" worden niet benoemd door de vergadering van aandeelhouders, doch door de beheerders. Zij zijn derhalve procuratiehauders met den titel van "directeur",

Ter illustratic van een en ander volgt hier een extract uit de Statuten van een groote Fransche onderneming.

\section{Titre III Administration}

La Société est administrée par un Conseil composé de six membres au moins et de seize au plus, nommés par l'Assemblée générale des actionnaires.

Le Conscil d'Administration a les pouvoirs les plus étendues pour gérer la Socićté, accomplir toutes les opérations à son objet et la représenter vis à vis des tiers.

\section{Titre IV Commissaires}

J'Assemblée désigne un ou plusicurs Commissaires chargés de faire un rapport à l'Assemblée générale de l'année suivante, sur la situation de la Société, sur lc bilan et sur les comptes présentés par les administrateurs. ........ Teur remunération est fixée par l'Assemblée générale.

Ten slotte nog een enkele opmerking.

In het bovenstande werd cr reeds op gewezen, dat niet alleen in Frankrijk de „Conseil d'Administration" de rennoot- schap bestuurt en haar vermogen beheert. Dezelfde figuur vindt men ook in België. In het Nederlandsch sprekende gedeelte van lat land gebruilst men de termen beheerders en commissarissen. In verband met de Belgische structuur sticht de letterlijke vertaling van ,,commissaires" aldaar echter" geen verwarring.

VAN DER SPII

Jk heb met zecr veel belangstelling gelezen het artikel, Nicuwe regeling van het toezicht op jaarrekeningen van Naamlooze Temnootschappen in Frankrijlk", hetwelk geplubliceerd is in het Februari-nummer van Uw Maandblad.

Jk meen echter niet te mogen nalaten $U w$ aandacht erop to vestigen, dat er - althans naar mijn meening - een misverstand in de strekking van het genocmde artikel is geslopen, dat het gevolg is van de onjuiste vertaling van het Fransche woord „commissaire" gelijk aan het Hollandsche woord commissaris (eener N.Y.), terwijl voor zoover mij bekend de Hollandsche functic ran Commissaris eener N.V. in Frankrijk genoend wordt "A dministrateur".

Met ,commissaire" bedoelt men de controleur van de jaarrekening, de functie derhalve, die bij ons veelal aan den accountant wordt opgedragen.

Ik moge nog ter adstructic van mijn opmerking een tweetal bepalingen citeeren uit het decleet van 8 Augustus 1935, welke bepalingen zijn opgenomen in het nieuwe artikel 33 van de wet van 24 Juli $186 \bar{\tau}$, van welk artikel het onderhavige decreet de nieuwe tekst heeft vastgesteld:

„Les commissaires inserits sur la liste de la cour d'appèl ,ne peuvent exercer les fonctions d'administrateur de ,société.

„Les commissaires ne peuvent pas devenir administra„teurs des sociétés qu'ils contrôlent moins de cinc années ,après l'expiration de leur mandat'.

'Terwijl hier dus de functies van commissaris (, administrateur"') en onafhankelijk controlemr van de jaarrekening (,,commissaire") onvereenigbaar worden genoemd, zegt de Heer' Haarbosch in zijn Naschrift op pg. 20 (2e kolom) van hetzelfde nummer o.a.:

„Nu komt echter de andere kant, nl. le accountants-zijcle ,van de aangelegenheid. Het is toch niet op losse gronden ,geweest, dat het N. I. v. A. bepaald heeft, dat de functic „,van commisaris bij dezelfde N.V. Toch is het blịkbaar "de bedocling van den Franschen wetgever deze beide „functies wèl in een persoon te vereenigen".

Het zal U duidelịk zịn, dat ik mịj met deze conclusic niet kan vereenigen on dat het artikel in zijn geheel m.i. niet het juiste licht werpt op de beteekenis van de desbetreffende nieuwe wetelijke bepalingen in Frankrijk; althans bij hen, die het onderwerp niet verder onderzoeken, verwarring kan stichten.

\section{M. DEEN Jr}

De inzenders hebben gelijk. Het burcau, dat wij met de vertaling hebben belast, heeft een leelijke fout gemaakt, die de beteckenis van de bepalingen belangrịk heeft gewijzigd.

REDACTIE 